\title{
Public Perception of Transportation Systems in The Halal Logistics
}

\author{
Ita Suhermin Ingsih*, Anita Rahmawati \\ Civil Engineering Department, Universitas Islam Malang, Malang, 65144, Indonesia \\ Ita.suhermin@gmail.com
}

Received 26-06-2020; accepted 10-08-2020

\begin{abstract}
The need for halal products has now become a trend. Not only struggling in food, but has grown in cosmetic, medicines and Islamic financial services industry. A research from the Pew Research Centre, states that until 2050, the world's Muslim population is expected to grow by 75 percent. This can be interpreted that the level of need for halal products is also increasing. Along with increasing public awareness of halal products, it is also necessary to treat halal in the logistics process. This research examines public perceptions regarding halal logistics, especially halal product transportation, and its variables are perceived by the community to be applied in halal logistics. The results of the study showed that more than $90 \%$ of respondents considered important variables needed in the implementation of halal logistics: mainly in sorting goods according to types as well as halal and non-halal, separating halal and non-halal products, setting the position of goods in cargo, using vehicles specifically for halal products, maintenance of cargo cleanliness, training of halal logistic officers, and health care for halal logistic officers. In addition, the use of halal logistic stickers can also provide halal logistic warranty from producers to consumers.
\end{abstract}

Keywords: Perception, Transportation, Halal Logistics

\section{Introduction}

One reason for the rise of the halal economy is that the global customer group of nearly two billion Muslims are younger and, in some places at least, richer than ever [1]. A research from the Pew Research Center, states that until 2050, the Muslim population in the world is expected to grow by 75 percent. This figure is double the population growth in the world which is estimated at 35 percent [2]. Demand from approximately 1.6 billion Muslims throughout the world has become a crucial door-opener for Halal industry [3]. Indonesia is the highest halal market potential in the world due to Indonesia's total population of 257.9 million and around $85 \%$ are Muslim, which is around 12.5 percent of the population worldwide. However, not many industries in the country have looked at business opportunities with this halal standardization. In a Muslim country such as Indonesia, halal products have the potential power to foster customer loyalty [4]. The problem in Indonesia with the halal market potential is currently still hitting the discourse. Indonesia is still limited to awareness of not daring to act, whereas in non-Muslim

Cite this as: Ingsih, I., \& Rahmawati, A. (2020). Public Perception of Transportation Systems in The Halal Logistics. Civil and Environmental Science Journal (Civense), 3(2), 95-101. doi: https://doi.org/10.21776/ub.civense.2020.00302.4 
countries many have implemented this halal supply chain. Conditions like this if not addressed wisely will certainly make the Indonesian people as spectators in their own country, especially in the competition of the ASEAN Economic Community (AEC). Halal logistics is the process of controlling the material flow and information flow throughout the supply chain by following the Halal standard [5]. The concept of Halalan Toyyiban has been introduced, where the concept starts from the farm until consumption. This means all the raw materials, material handling, storage, warehousing, and transportation should use the halal concept across the supply chain [6]. Halal is extending towards logistics. This paper proposes a halal assurance system for transportation, warehousing and terminals as a proof of a halal logistics system [7]. The consumer opinion is necessary to measure, to develop a logistical standard and to conclude where the Critical Control Points (CCPs) of the halal food chain really are [8]. Referring to Malaysia's halal standard supply chain (halal supply chain), there are 3 (three) criteria for halal logistics standardization, namely: 1. Goods transportation services; 2. Warehousing activities; 3. Sales [9]. Based on the above matters, the author needs to know how the perception of a small population of consumers in Indonesia, who are predominantly Muslim, is about the halal logistics system in transportation variable and how high is the public's attention on the halal logistics system, especially in transportation of goods.

\section{Material and Methods}

\subsection{Location and Time of Study}

The study was conducted in October 2019 located in Malang City, Indonesia by taking a sample of the general public around The University of Islam Malang and surrounding involving students, employees, lecturers and the general public.

\subsection{Data Collection}

The methods used in collecting data were interview and questionnaire. The selected respondents are workers with a minimum high school education level and conducted on 89 respondents. With getting data directly by questionnaire and interviews in spare time, will be obtained data which can be taken up by the respondent in answering existing questions.

\subsection{Data Processing}

The data analysis used qualitative descriptive method. The analysis based on the results of closed questionnaire recapitulation, in which the respondent is directed to choose an answer that is in accordance with the respondent's perception. While the interview survey is open, so that respondents are expected to give their opinions freely in the form of narration.

\section{Result and Discussion}

Respondents who were the focus of this study were classified based on several types of characteristics, namely gender, education level, and respondent's occupation. Sampling amounted to 89 respondents, which have various characteristics. For more details about the characteristics of the respondents will be presented in several diagrams below.

\subsection{Test Validity and Reliability of the Questionnaire}

Based on the results of the distribution of questionnaires to 89 respondents about the public perception of transportation for halal products, the following data were obtained. From the results of a closed questionnaire conducted on the general public, this questionnaire directed respondents to assess the level of importance of each variable, namely the first variable up to the Nine variable symbolized by (x1 to x9). The importance level is in the form of Very Not Important (value 1), Less Important (value 2), Neutral (value 3), Important (value 4), and Very Important (value 5). The above assessment is in addition to measuring the level of validity and the level of reliability of the questions contained in the questionnaire, also to determine public perceptions of what treatments need to be applied to the 
implementation of Halal Logistics Transportation activities. Testing the validity and reliability of the questionnaire aims to find out whether the contents or data of the question items are valid (valid) and reliable (reliable). If the data from the question items are valid and reliable, then the data can be used to measure the content of existing instruments. In Table 1. The results of the Validity Test, obtained the value of the validity of variables $\mathrm{x} 1$ to variable $\mathrm{x} 9$ are above the value of $\mathrm{r}$ Table $(0.142)$, which varies between values 0.6 to 0.8 . So it can be said that the variables contained in this questionnaire are valid. Next is the reliability test using the Cronbach alpha formula with reference to the standard alpha value [10]. Cronbach alpha value obtained for public perception of halal logistics transportation is 0.85111 , can be said to be very reliable because it is worth more than 0.8 and less than 1 .

\subsection{Respondents Characteristics}

This study was dominated by 62 male respondents (70\%) and 27 female respondents (30\%). based on the level of education that is senior high school graduates, Bachelor, Magister, and Doctoral (Figure 1). Also was dominated by Senior high school graduate respondents totaling 61 people $(69 \%)$, then Bachelor graduate respondents totaled 4 people (4\%), Magister graduates totaling 22 people $(25 \%)$ and Doctoral graduates totaling 2 people (2\%) (Figure 2).

\subsection{Discussion}

In this research, a perception of transportation services for halal products, the community gives a response about what they get and expect. Analysis of this variable can be used as an illustration of the data instrument. The first step taken to analyse the data is by arranging them according to the number of statements for each variable.

1. The term supply chain or halal logistics supply chain (Figure 3).

2. Consumption of halal products (for example: food, cosmetics, medicines, clothes, etc.) (Figure 4).

3. Sorting items according to type (x1) (Figure 5).

4. Separation of halal and non-halal products in cargo (x2) (Figure 6).

5. Sorting of halal and non-halal products that have been damaged (x3) (Figure 7).

6. Positioning the placement of halal and non-halal goods in cargo vehicles (x4) (Figure 8).

7. Use of special vehicles in the delivery of halal products (x5) (Figure 9).

8. Cleanliness and avoid contamination between products in cargo vehicles (x6) (Figure 10).

9. Regularly training goods delivery personnel on halal logistics (x7) (Figure 11).

10. Special training for officers on how to treat halal products (x8) (Figure 12).

11. Health care for workers sending goods, especially officers shipping halal products (x9) (Figure 13).

While the results of the open questionnaire survey of several respondents have different perceptions related to halal logistics transportation in Indonesia. Some of these responses are: 1). Some respondents, even the majority consider that the separation of halal products from non-halal products placed in separate containers is very important. This mean to avoiding (cross) contamination, avoiding mistakes, and ensuring that operations are consistent with the expectations of the Muslim consumer [8][11]. The separation of halal and non-halal products in a different container or container is considered as a form of religious prudence and also a form of religious tolerance that needs to be maintained as well as possible. Not only Muslim consumers, but also non-Muslim consumers. In general, various socioeconomic/demographic factors such as education level, older generation, those who are more religious and the urban dweller seem to more likely to be aware of the advantages of Halal principles [12]. 2). The separation of halal and non-halal products is part of a different container or container is considered as a form of caution in religion and is also a form of religious collection that needs to be maintained properly. 


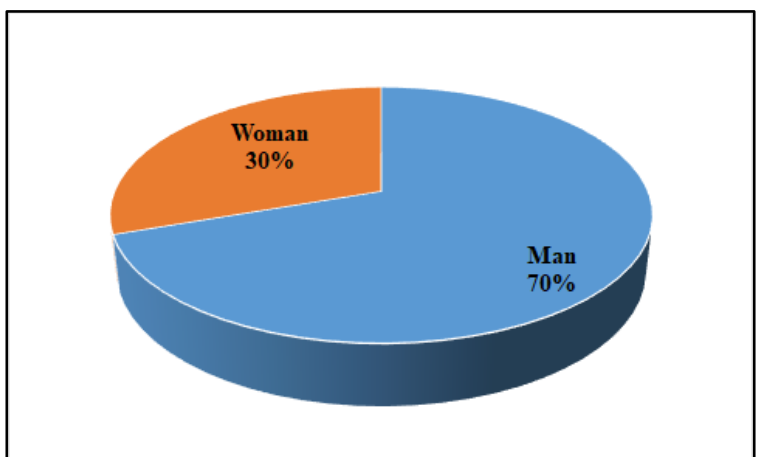

Figure 1. Characteristics of Respondents by Gender

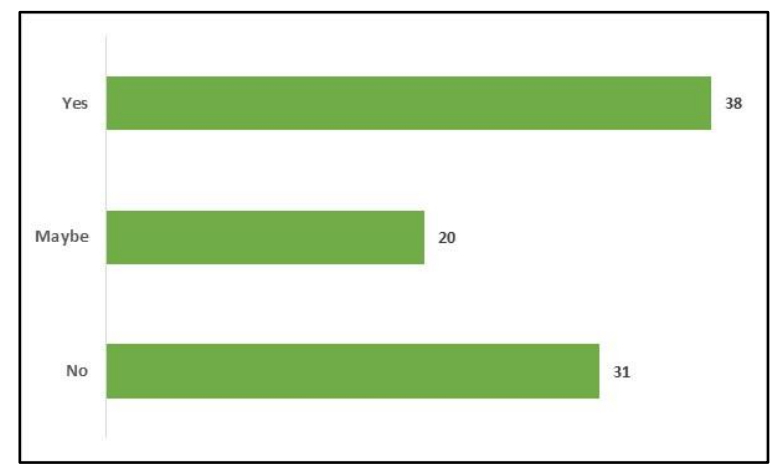

Figure 3. The term supply chain or halal logistics supply chain

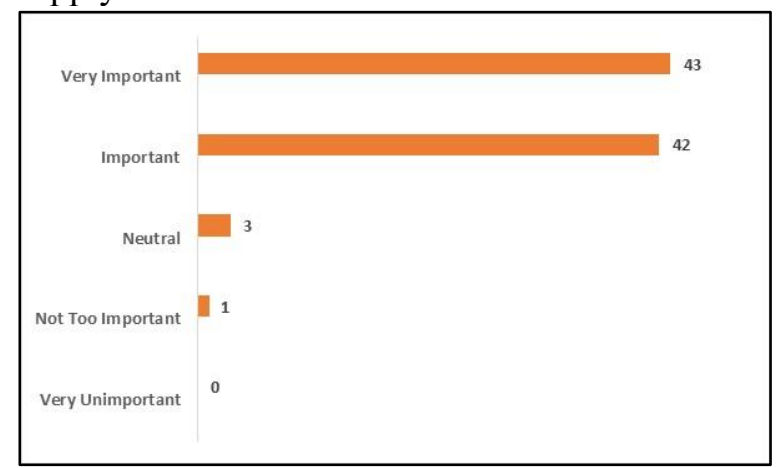

Figure 5. Sorting items according to type

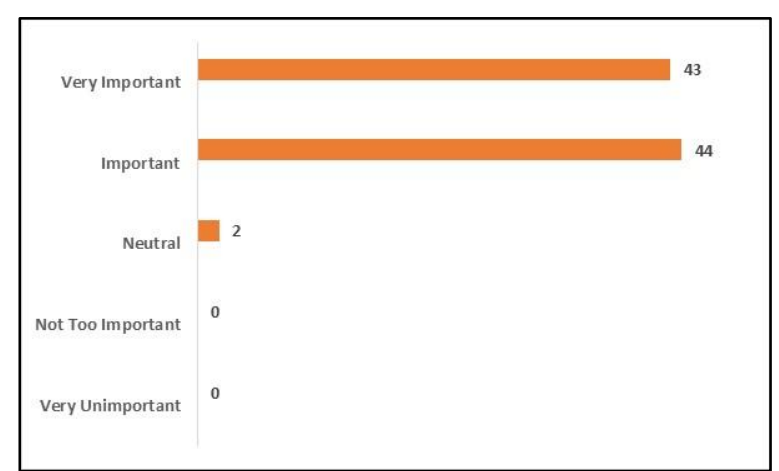

Figure 7. Sorting of halal and non-halal products that have been damaged

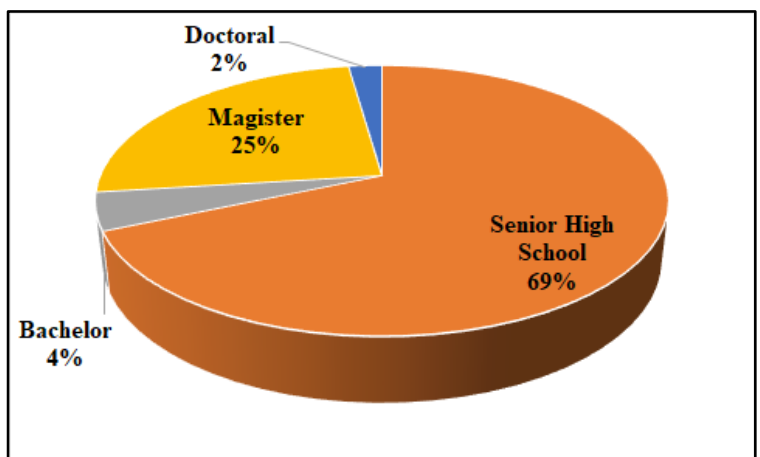

Figure 2. Characteristics of Respondents Based on the Latest Education Level

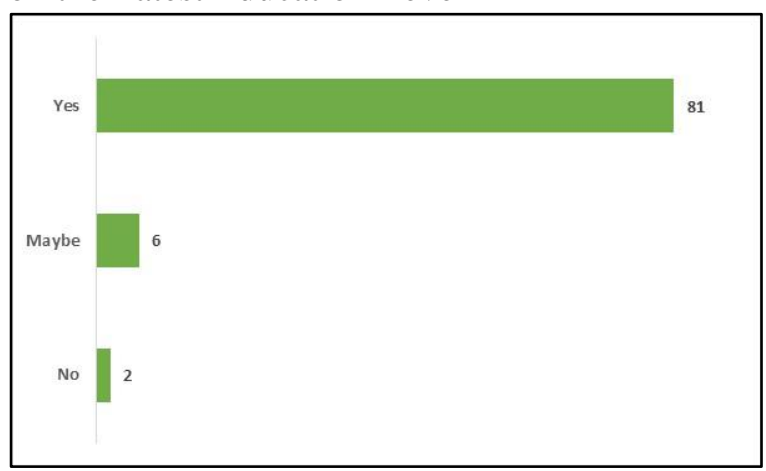

Figure 4. Consumption of halal products

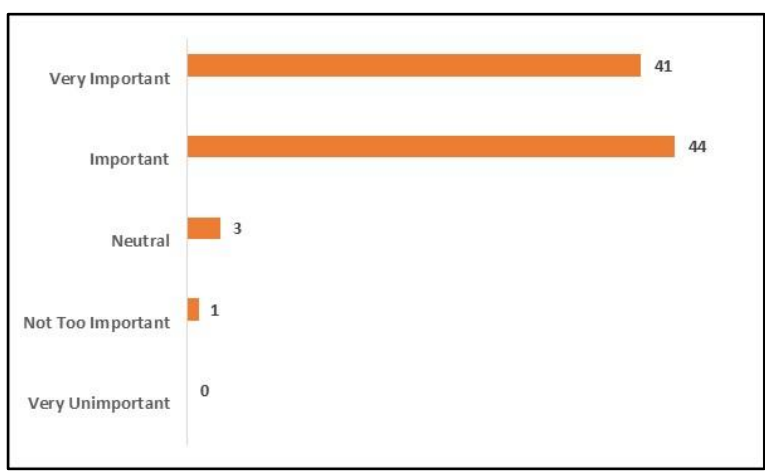

Figure 6. Separation of halal and non-halal products in cargo

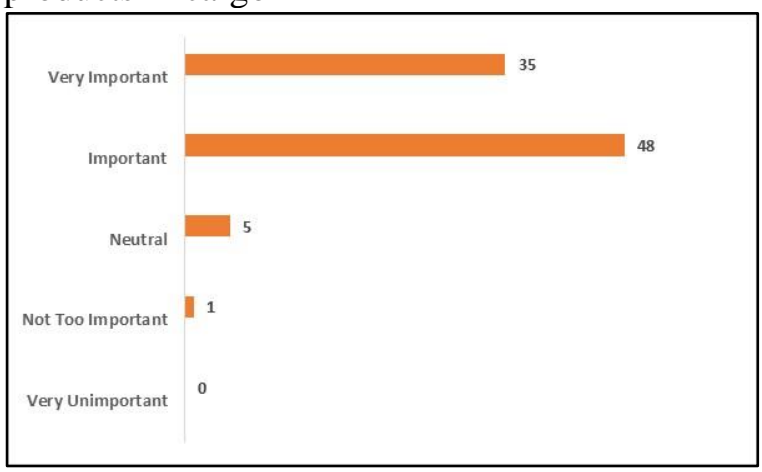

Figure 8. Positioning the placement of halal and non-halal goods in cargo vehicles 


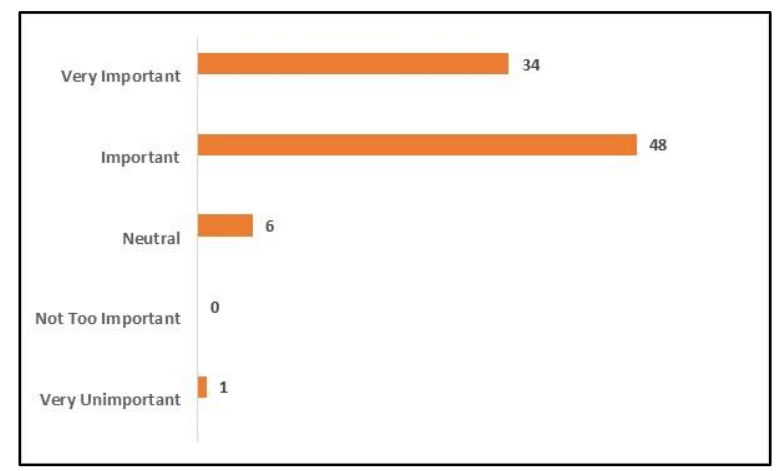

Figure 9. Use of special vehicles in the delivery of halal products

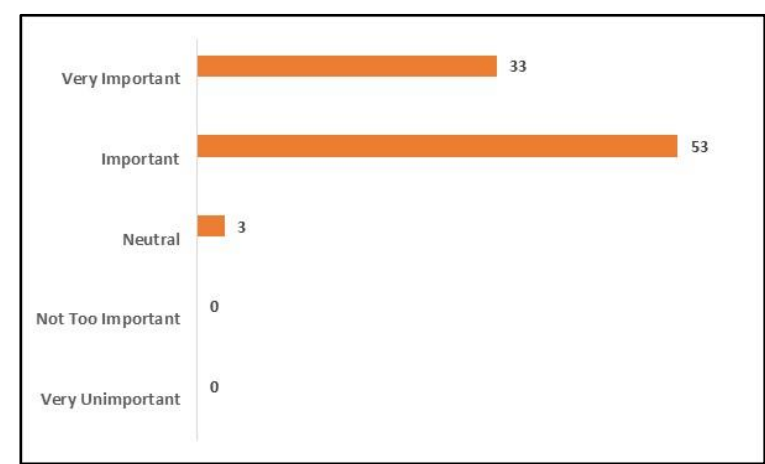

Figure 11. Regularly training goods delivery personnel on halal logistics

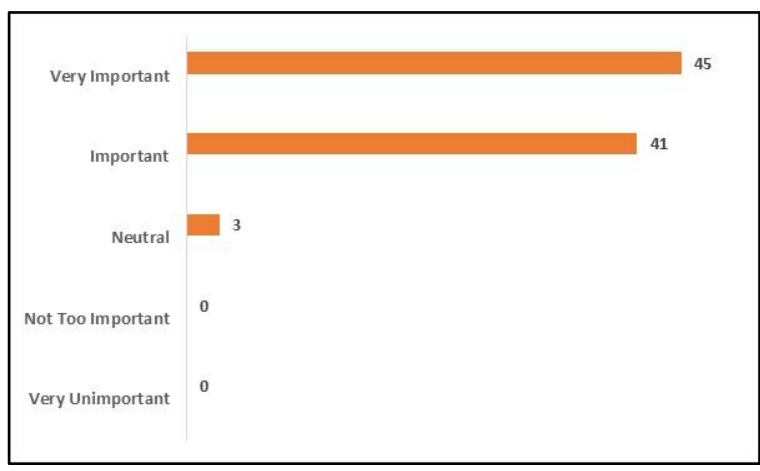

Figure 10. Cleanliness and avoid contamination between products in cargo vehicles

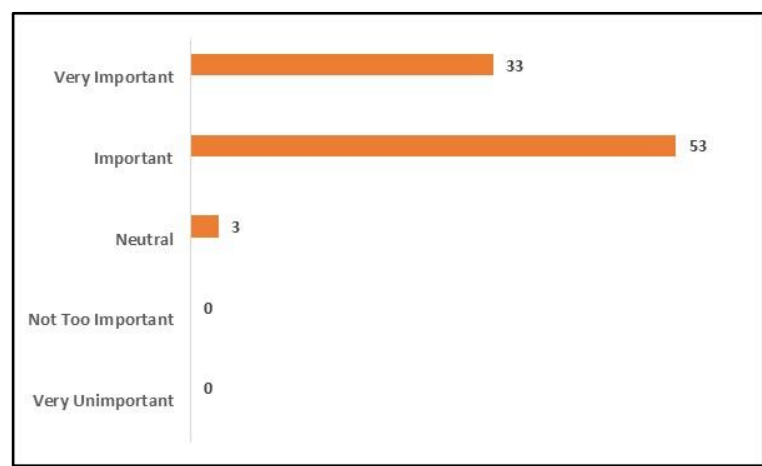

Figure 12. Special training for officers on how to treat halal products

Table 1. Validity Test Results

\begin{tabular}{|c|c|c|c|}
\hline Variabel & r Table & \multicolumn{2}{|c|}{ Validity } \\
\hline $\mathrm{x} 1$ & 0.142 & 0.601959 & $\mathrm{OK}$ \\
\hline $\mathrm{x} 2$ & 0.142 & 0.831832 & $\mathrm{OK}$ \\
\hline $\mathrm{x} 3$ & 0.142 & 0.730957 & $\mathrm{OK}$ \\
\hline $\mathrm{x} 4$ & 0.142 & 0.748228 & $\mathrm{OK}$ \\
\hline $\mathrm{x} 5$ & 0.142 & 0.838175 & $\mathrm{OK}$ \\
\hline $\mathrm{x} 6$ & 0.142 & 0.753449 & $\mathrm{OK}$ \\
\hline $\mathrm{x} 7$ & 0.142 & 0.805823 & $\mathrm{OK}$ \\
\hline $\mathrm{x} 8$ & 0.142 & 0.842556 & $\mathrm{OK}$ \\
\hline $\mathrm{x} 9$ & 0.142 & 0.869852 & $\mathrm{OK}$ \\
\hline
\end{tabular}

3). The importance of sorting products that have passed the end of their useful life (expired) and also products that are damaged or unsuitable for sale or consumption by consumers, which in turn will impact on the health of consumers. 4). Shipping logistics both halal and non-halal products by train, to save on shipping costs and reduce the volume of vehicles on the highway. 5). At this time, the role of relevant stakeholders is only the type of goods listed in the manifest of goods entering or leaving the port. The owner of the goods, especially refer container, needs to sort out between halal and non-halal, given the consumption patterns in our country with a variety of religions and cultures. Sometimes the goods owner can only mix between halal and non-halal to reduce shipping costs. So, expect education about halal logistics from upstream to downstream. 6). Respondents hope that there will be cargo companies that implement the separation of halal and non-halal products. If there is no cargo company that is willing to share this halal product idea. It is better if there is a Muslim entrepreneur initiative to pioneer cargo 
services that are willing to serve the separation of halal products. 7). There needs to be extensive socialization to the public so that the whole community is concerned about the halal logistics system, so that there will be direct supervision from the public if there are deviations in the implementation of logistics for halal products. 8). The current pattern of shipping goods is in accordance with the SOP and the security is quite good, because every item to be sent is pre-packed/neatly wrapped from the factory or the owner of the goods so that the shipping officer at the port only repackages if there is damage. The shipping of goods has always been safe because the goods sent are solid goods/not raw goods so it does not cause risk of contamination. 9). There must be a clear and straightforward standard/SOP in managing this matter, and the commitment of all stakeholders to implement it. If this logistics process can be run more efficiently, it is not impossible for Indonesia to become a market leader in the business.

In Malaysia, the concept of Halalan Toyyiban has been introduced, where the concept starts from the farm until consumption. This means all the raw materials, material handling, storage, warehousing, and transportation should use the halal concept across the supply chain.

There are even already a number of Halal Logistics Service Providers (LSP). There was only one LSP company that introduced this new concept in their operation, there is about nine companies certified with Halal Logistics Certificate [6]. Controlling 'Halal' in logistics activities is monitoring Halal performances in transportations activities that should comply with the Shariah principle [13]. Determining few risks in the transportation process of halal logistics are needed. There are few risk categories that lead to contamination risk of halal food products during the transportation, storage, and distribution process in halal food supply chain. Delay risk, natural hazard, and operational risk are the category of risks that would affect the halal food products safety and quality and halal status during the transportation process. Similarly, technology adoption risk and halal integrity risk are also important risk factors towards the process of risk categorization in halal food transportation and distribution process [14].

Using technology also can be provided in transportation of halal logistics, for example ICT (Information Communication Technology). Three important element that is considered an important step when deciding to adopt ICT for Halal transportation which are: a). Assessing the Halal Transportation's requirement $b$ ). Validating the need for technology specifically for Halal Transportation Controls and c). Assessing organizational capabilities or readiness - activate halal transportation critical controls through ICT assistance. Technology related factors (ICT compatibility with Halal requirement) and Halal assurance related factors are the most crucial factors among the Halal LSPs applying ICT for Halal control in transportation-s operation [15]. This is because transportation cannot be separated from information technology [16]. There is a need to develop proper guidelines, standards and codes, to train the Halal logisticians. Robust ICT and its appropriate implementation seems as the backbone of the HSC (Halal Supply Chain) [17]. ICT technology can also be applied to agricultural products and fresh fish [18].

\section{Conclusions}

More than $90 \%$ of respondents consider that variables 1 through 9 are important and very important in the implementation of the transportation system for halal products. The importance of using separate vehicles for the transportation of halal products and non-halal products. In the using same vehicle, it is necessary to place halal products in separate containers with non-halal products. In using same container, it is necessary to set the position or position separately and in such a way between halal and non-halal products. Special training is needed for officers who will handle halal products in this halal logistics. Such as vehicle cleaning that must be in accordance with the Mahzab Shafi'I (Law), as well as other requirements because halal products are still maintained halal and obedience. Halal logistics costs can be reduced by the use of vehicles and routes separate from general logical transportation. And also, the use of halal stickers can be used as a guarantee of halal (halal logistics warranty) for consumers.

Research on halal transportation is not only limited to perception, but can be developed to logistical service providers. Another thing that can also be developed is knowing non-Muslim perceptions of halal logistical services. 


\section{References}

[1] M. Asrofi, "Halal Logistics Business Potential in Indonesia," Frost \& Sullivan Market Insight, 2011.

[2] databoks, "https://databoks.katadata.co.id/datapublish/2017/01/31/penduduk-muslim-tumbuhtercepat-di-dunia," 2017. https://databoks.katadata.co.id/datapublish/2017/01/31/pendudukmuslim-tumbuh-tercepat-di-dunia.

[3] N. S. N. M. Yunus, W. E. W. Rashid, N. M. Ariffin, and N. M. Rashid, "Muslim's Purchase Intention towards Non-Muslim's Halal Packaged Food Manufacturer," Procedia - Soc. Behav. Sci., 2014, doi: 10.1016/j.sbspro.2014.04.018.

[4] I. Masudin, F. W. Fernanda, and Widayat, "Halal logistics performance and customer loyalty: From the literature review to a conceptual framework," Int. J. Technol., 2018, doi: 10.14716/ijtech.v9i5.1919.

[5] M. Shahril Ahmad Razimi, A. Rahim Romle, and A. Mohd Rashid, "The Halal Concept on Logistic Islamic Practices in Malaysia," Eur. J. Appl. Sci., 2017, doi: 10.5829/idosi.ejas.2017.11.15.

[6] N. F. Roslan, F. A. Rahman, F. Ahmad, and N. I. Ngadiman, "Halal logistics certificate in Malaysia: Challenges and practices," Int. J. Supply Chain Manag., 2016.

[7] M. Tieman and M. C. Ghazali, "Halal Control Activities and Assurance Activities in Halal Food Logistics," Procedia - Soc. Behav. Sci., 2014, doi: 10.1016/j.sbspro.2014.01.1107.

[8] R. Bruil, "Halal logistics and the impact of consumer perceptions," Master Thesis R.R. Bruil, 2010.

[9] Malaysian Standard 2004-1:2010, Halalan-Toyyiban Assurance Pipeline - Part 1: Management System Requirements for Transportation of Goods and/or Cargo Chain Services. Malaysia, 2004.

[10] T. P. Budi, Paradigma Baru Manajemen Sumber Daya Manusia. Yogyakarta: Tugu Publisher, 2005.

[11] H. A. Tarmizi, N. H. Kamarulzaman, I. A. Latiff, and A. A. Rahman, "Factors behind thirdparty logistics providers readiness towards halal logistics," Int. J. Supply Chain Manag., 2014.

[12] V. N. Mathew, A. M. R. binti A. Abdullah, and S. N. binti M. Ismail, "Acceptance on Halal Food among Non-Muslim Consumers," Procedia - Soc. Behav. Sci., 2014, doi: 10.1016/j.sbspro.2014.01.1127.

[13] N. W. R. Shah, A. Muhammad, S. Mohamad, and H. S. Jaafar, "Halal Transportation Providers for Supply Chain Management in Halal Industry: A Review," J. Hosp. Networks, 2016.

[14] T. Z. Yaacob, F. A. Rahman, and H. S. Jaafar, "Risk categories in halal food transportation: A preliminary findings," Int. J. Supply Chain Manag., 2018.

[15] M. I. I. Tan, R. N. Razali, M. I. Desa, and Z. J. M. Husny, "Information Communication Technology adoption process for Malaysia Halal Transportation," in Lecture Notes in Engineering and Computer Science, 2014.

[16] Qurtubi and E. Kusrini, "Research in halal logistics and halal supply chain: Issue and area development," in MATEC Web of Conferences, 2018, doi: 10.1051/matecconf/201815401096.

[17] A. Haleem and M. I. Khan, "Towards successful adoption of Halal logistics and its implications for the stakeholders," Br. Food J., 2017, doi: 10.1108/BFJ-12-2016-0637.

[18] T. G. Amran, "Design of Cold Chain Third-Party Logistics (3Pl) for Halal Food in Indonesia," Proceeding 8 th Int. Semin. Ind. Eng. Manag., 1978. 